\title{
New species of Bakeriella (Hymenoptera, Bethylidae) from the New World and new data on geographic distribution
}

\author{
Ricardo Kawada ${ }^{1,2}$ \\ Celso Oliveira Azevedo ${ }^{1,3}$
}

\begin{abstract}
Aвstract. Bakeriella lata sp. nov. (Brazil, Rondônia), Bakeriella aurata sp. nov. (Brazil, Amazonas) and Bakeriella sulcaticeps sp. nov. (Brazil, Amazonas) are described and illustrated. New geographic records and variation data for $B$. cristata Evans, 1964, B. floridana Evans, 1964, B. flavicornis Kieffer, 1910, B. incompleta Azevedo, 1994, B. mira Evans, 1997, B. montivaga (Kieffer, 1910), B. olmeca Evans, 1964 and B. subcarinata Evans, 1965 are provided. The male of $B$. incompleta is described for the first time.
\end{abstract}

Keywords. Bakeriella; Bethylidae; Hymenoptera; Neotropical; taxonomy.

\section{INTRODUCTION}

Bakeriella Kieffer, 1910 is one of the most sculptured genera of Bethylidae. Most of its species has pronotal disc carinate, scutellar pits rectangular and large, and propodeal disc with paramedian carinae typically arched. There are 22 known species restricted to the New World, and herein three new species from Brazil are described. The male of $B$. incompleta Azevedo, 1994 is also described.

The material examined was provided by the following institutions: CNCI - Canadian National Collection of Insects, Canada (J. T. Huber); DZUP - Universidade Federal do Paraná, Brazil (K. Zanol); DCBU - Universidade Federal de São Carlos, Brazil (A. M. Penteado-Dias); EMUS - Utah State University, USA (W. J. Hanson); INPA - Instituto Nacional de Pesquisas da Amazônia, Brazil (C. Magalhães); MPEG - Museu Paraense Emílio Goeldi, Brazil (A. Harada); OSUC - Ohio State University, U.S.A. (N. Johnson); UFES - Universidade Federal do Espírito Santo, Brazil (author); UFMG - Universidade Federal de Minas Gerais, Brazil (F. Silveira).

The nomenclature of the integument sculpture follows HARRIS (1979). Terminology generally follows Evans (1964). The main measurements and indices used in this study are as follow: LH, length of head; WH, width of head; WF, width of frons; HE, height of eye; OOL, ocello-ocular line; WOT, width of the ocellar triangle; DAO, diameter of anterior ocellus; distance of the ocellar triangle to vertex; distance from posterior ocellus to vertex crest; VOL, vertex-ocular line; distance from the eye top to vertex crest; LFW, length of fore wing.

\section{Bakeriella polita Evans, 1964}

(Figs. 1, 9, 15, 22, 29, 30)

Bakeriella polita Evans, 1964: 120 (key), 130; 1979: 263, 259 (key); Gordh \& Moczar, 1990: 71 (cat.); Azevedo, 1994: 148, 149 (key).

This species was known from Bolivia (1 male) and from Peru (3 males), and now it is recorded from Brazil. Genitalia: paramere long, wide at the base and narrowing gradually to the apex; volsella with cuspis deeply divided in two arms, slightly longer than the half of the paramere and rounded apically and digitus as high as cuspis; aedeagus bottle-shaped (Figs. 29, 30).

Material examined. BRAZIL. Amapá: 1 male, Serra do Navio, 10.VII.1961, J. \& B. Beckyné col. (MPEG); 2 males, Rio Calçoene, Ig. do Tigre, 6-8.VIII.1961, J. \& Bechyné, B. col. (MPEG). Pará: 1 sex undefined, Serra Norte Serraria, Ig. Azul, 20-24.VI.1985, Ramos, R. R. col. (MPEG). Mato Grosso: 2 males, Alta Floresta, Fazenda 3 Corações, 3-7.IV.1994, Möricke trap, Soares \& Joaquim col. (DCBU).

\footnotetext{
1. Universidade Federal do Espírito Santo, Departamento de Biologia. Av. Marechal Campos 1468, Maruípe, 29040-090 Vitória-ES, Brazil. E-mail: kawada@terra.com.br and cazevedo@npd.ufes.br

2. Bolsista de iniciação científica PIBIC/CNPq-UFES.

3. Pesquisador do CNPq.
} 


\section{Bakeriella subcarinata Evans, 1965}

(Figs. 2, 10, 20, 23)

Bakeriella subcarinata Evans, 1964 (1965): 271; Gordh \& Moczar, 1990: 72 (cat.); Azevedo, 1994: 145, 149 (key).

This species was known from Peru.

Material examined. MEXICO. Chiapas: 1 female, Ocosingo, 12.VI.1969, Bright \& Campbell col. (CNCI).

\section{Bakeriella mira Evans, 1997}

(Figs. 3, 11, 16, 24, 33, 34)

Bakeriella mira Evans, 1997: 177.

This species was known only from the Neartic region (Florida). Genitalia: paramere long, as long as the basiparamere, gradually widened to the rounded apex; volsella with cuspis narrowing evenly to the rounded apex, longer than digitus and slightly shorter than paramere; aedeagus bottle-shaped, with apex rounded and without pre-apical constriction (Figs. 33, 34).

Material examined. USA. Texas: 1 male, Cameron Co. Brownsville, Sable Palm Grove, 31.VI-10.VIII.1984, FIT, M. Kaulbars col. (CNCI). Florida: 1 male, Gainesville, 15-22.IV.1987, Hardwd. Forest, Malaise trap, Wahl \& Mason col. (CNCI). MEXICO. Quintana Roo: 2 males, Xei-Ná, trail in Coastal Resort, forest, 7.XII.1993, L. Masner col. (CNCI). Yucatan: 1 male and 1 sex undefined, Childen, Itzá, second forest, 17.XII.1993, L. Masner col. (CNCI).

Bakeriella incompleta Azevedo, 1994

(Figs. 4, 5, 12, 21, 25, 31, 32)

Bakeriella incompleta Azevedo, 1994: 146, 149 (key).

This species was known from São Paulo, Brazil (AzEvEDo 1994), 2 females. The male is described for the first time.

Male: length $7.3 \mathrm{~mm}$; LFW $4.8 \mathrm{~mm}$; WH 1.06 x LH; WF 0.64 x WH; WF 1.37 x HE; WOT 0.71 x OOL; posterior ocelli distant from the vertex crest $2.0 \times$ DAO; distance from the top eyes to the crest vertex $0.7 \mathrm{x}$ HE (Fig. 4). Temples with a carina which parallels along the extension (Fig. 5). Mandible with 5 teeth (Fig. 12). Pronotal disc with a very strong carina and angulate and projected outward in the corners; median carina complete and very weak; lateral carinae nearly complete behind (Fig. 21). Genitalia: paramere longer than wide; cuspis divided in two cylindrical rami and with rounded apex, digitus and cuspis slightly higher than the half of the paramere; aedeagus bottleshaped (Fig. 31-32). Mesopleuron with a very broad shallow fovea (Fig. 25).

Material examined. BRAZIL. São Paulo: 2 females, Bálsamo, 30.III01.X.1988, Möricke trap (UFES); 13 females and 7 males, Ibitinga, 01.VI.1988-26.VII.1989, Möricke trap (UFES). Paraná: 1 female, Telêmaco Borba, Reserva Samuel Klabin, 07.XII.1987, Malaise trap,
PROFAUPAR survey (DZUP).

\section{Bakeriella lata sp. nov.}

(Figs. 6, 13, 18, 26)

Description. Female. Length 7.4 mm; LFW 5.4 mm; head and mesosoma black; metasoma, legs and clypeus dark castaneous; antennae, mandibles and palpi castaneous; wings subhyaline.

Head (Fig. 6). Mandible with five teeth gradually larger downward, the three upper rounded and two lower sharpened (Fig. 13). Clypeus with median lobe obtusely angulate. First four antennal segments in a ratio of 35: 10: 10: 13; segment XI thicker than long; flagellar pubescence short and appressed, with some setae long and erect. Antennal scrobes not carinate, but antennal toruli with a short carina. Frons weakly coriaceous with small punctures. Eyes weakly hairy. WH 0.94 x LH; WF 0.59 x WH; WF 1.18 x HE; OOL 1.75 x WOT; posterior ocelli distant from the vertex crest $3.6 \times$ DAO. Vertex straight with corners slightly angled. VOL $0.69 \times \mathrm{HE}$.

Mesosoma (Fig. 18). Weakly coriaceous. Pronotal disc with anterior corners acute, median carina strong, complete, welldefined and wide especially anteriorly, laterally paralleled by a strong linear depression; anterior transversal carina straight, toothed internally, lateral of the disc acute, posterior margin polished, paralleled by a series of small foveae. Notauli complete, slightly widened and convergent behind. Parapsidal furrows straight, well-defined and incomplete anteriorly. Scutellar pits wider than long, separated by a thin septum. Scutellum not reaching propodeum. Propodeal disc 0.92 times wider than long, with median carina complete, paramedian carinae incomplete, convergent behind, space between them with weak transverse striae; disc with an anterior quadrate depression beside the paramedian carinae; posterior corners foveolate; declivity with median carina complete. Mesopleuron with a complete and large fovea which occupies all surface of mesopleuron and with a elliptical central pit (Fig. 26). Fore femora 2.4 times longer than thick. Mid tibiae strongly spinose.

Material examined. Holotype female, BRAZIL, Rondônia, Ouro Preto do Oeste, Reserva INPA, 25-28.VIII.1986, Malaise trap (1.6m), F. F. Ramos col. (MPEG). Paratypes. BRAZIL. Amapá: 1 female, Serra do Navio, 18.V.1989, Malaise trap (1.6 m), Gorayeb, I. S. col. (MPEG). Amazonas: Manaus, 1 female, Campus Universitário, 31.VIII.1979, Malaise trap, Kleim, B. col. (INPA), 1 female, Reserva Ducke, stick trap (2m) 25-29.VII.1992, Vidal, I. \& Vidal, J. col. (INPA), 1 female, $26 \mathrm{Km}$ NE Manaus, igarapé, light trap, 8-10.VIII.1981 (OSUC). Pará: 1 female, Serra dos Carajás, Ig. Ipojuca, 17.V.1984, Malaise trap (2m) (MPEG), 1 female, Serra Norte, estrada do Manganês, 09-12.II.1985, Malaise trap (1.6m) (MPEG), 1 female, Serra Norte, Fefora, 7-10.IX.1985, Malaise trap (2m) (MPEG); 1 female, Oriximixá, Alcoa Mine Ração, Rio Trombetas, 7-25.X.1982, Malaise trap, Binda, R. \& Vidal, C. D. C. col. (OSUC). Rondônia: 2 females, Ouro Preto do Oeste, linha 212 lote 36 gleba 21-B, 1-5.IX.1986, F. F. Ramos, col. (MPEG), 1 female, Ji-Paraná Gleba, 25-28.II.1983, J. Arias \& equipe col. (OSUC). Paraná: 1 female, Telêmaco Borba, Reserva Samuel Kablin, 10.XI.1986, 1 female, Jundiaí do Sul, Fazenda Monte Verde, 30.XI.1987, Malaise trap, PROFAUPAR survey (DZUP).

Variations. Eyes glabrous; median carina of the pronotal 

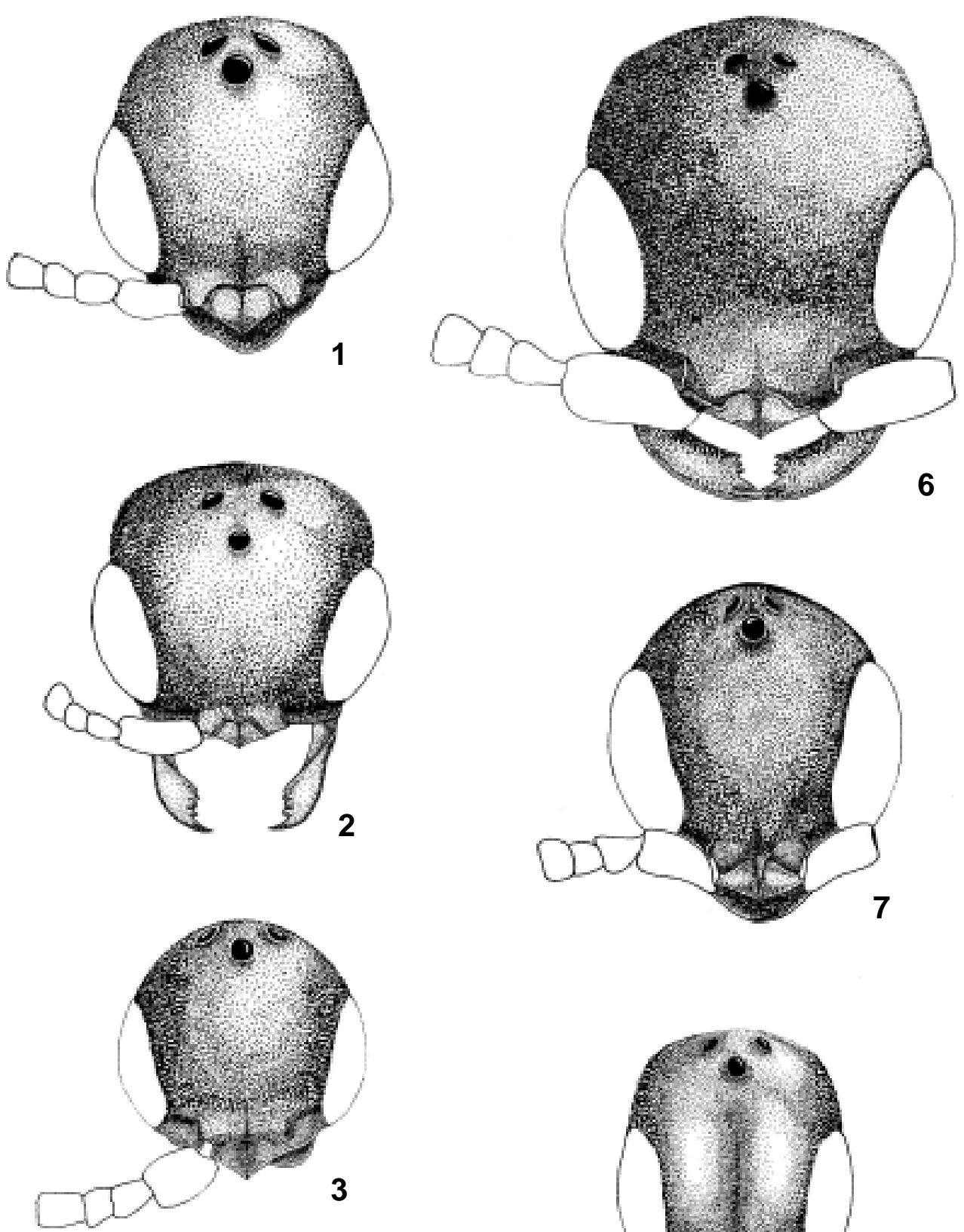

7
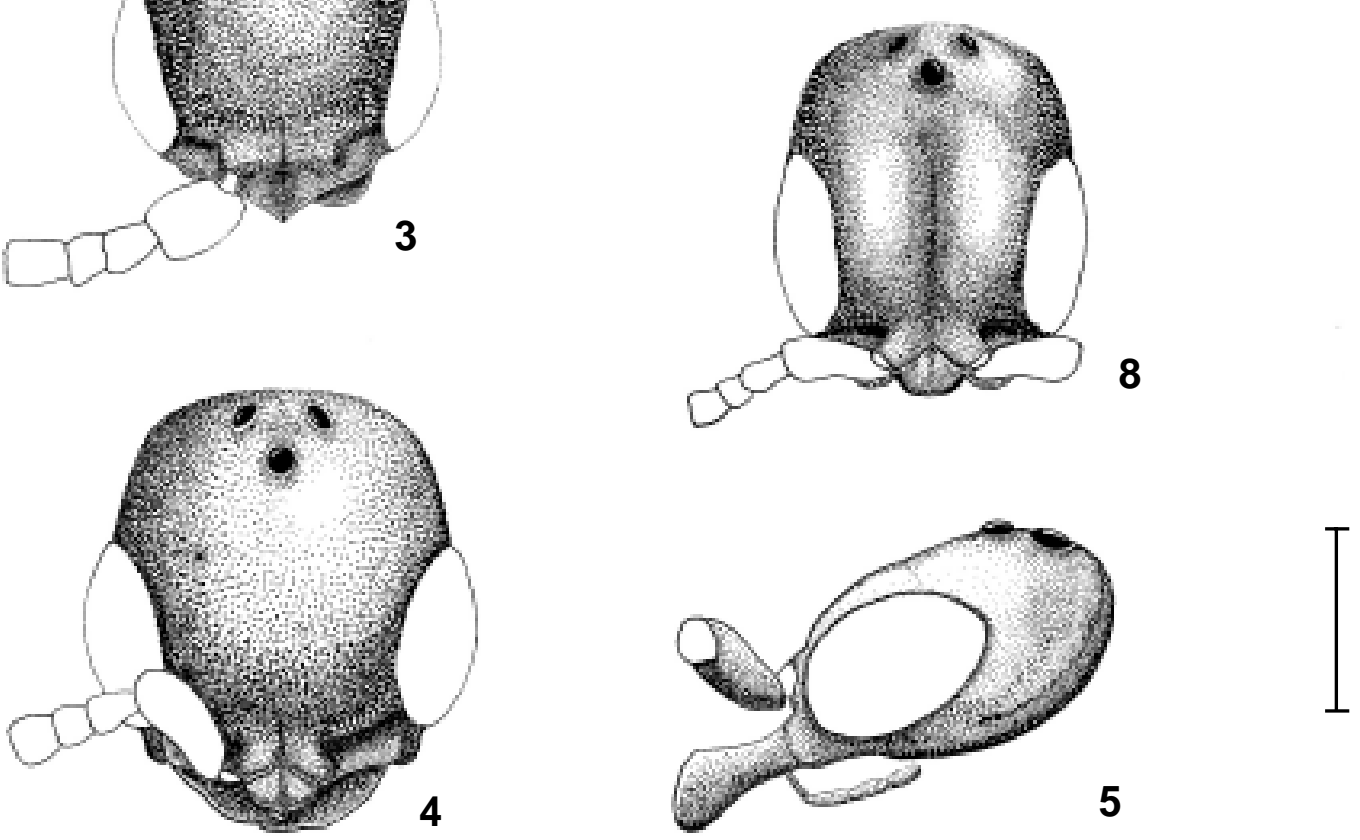

Figs. 1-8. Head. 1-4, 6-8, frontal view, 5, lateral view. 1, Bakeriella polita Evans, 1964; 2, B. subcarinata Evans, 1965; 3, B. mira Evans, 1997; 4-5, B. incompleta Azevedo, 1994; 6, B. lata sp. nov.; 7, B. aurata sp. nov.; 8, B. sulcaticeps sp. nov.; scale $=250 \mu \mathrm{m}$. 


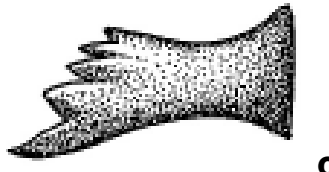

9

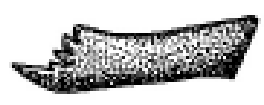

10

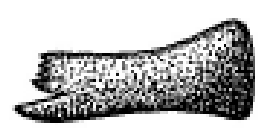

11

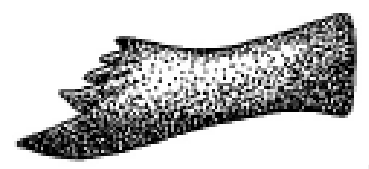

12
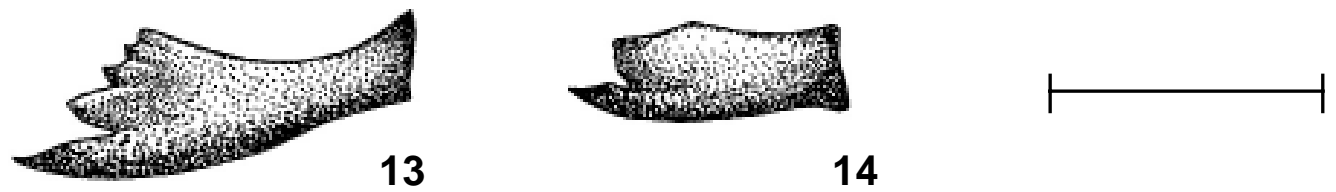

14

Figs. 9-14. Mandible, frontal view. 9, Bakeriella polita Evans, 1964; 10, B. subcarinata Evans, 1965; 11, B. mira Evans, 1997; 12, B. incompleta Azevedo, 1994; 13, B. lata sp. nov.; 14, $B$. aurata sp. nov.; scale $=250 \mu \mathrm{m}$.

disc with a small longitudinal concavity, wider or very thinner; notauli wider; striae between the space of the paramedian carinae stronger.

Remarks. This species differs from the other of this genus by having the median carina of pronotal disc very wide.

Etymology. The name refers to the wide carina of the pronotal disc.

\section{Bakeriella aurata sp. nov.} (Figs. 7, 14, 17, 27)

Description. Female. Length $5.0 \mathrm{~mm}$; LFW $3.9 \mathrm{~mm}$; head and mesosoma black with metallic golden reflections, propodeum black, metasoma, coxae and femora dark castaneous, antennae and mandibles castaneous, palpi light castaneous, fore wings subhyaline darkened around radial vein.

Head (Fig. 7). Mandibles with two teeth wide, large and sharpened, the lower largest (Fig. 14). Clypeus with median lobe rounded, median carina incomplete. Antennal scrobes not carinate. First four antennal segments in a ratio of 40:13:10:14; flagellar pubescence short and subappressed, with some long setae, erect and suberect. Frons weakly coriaceous with small punctures, 0.3-1.0 time their own diameters. Eyes with sparse hairs. WH 1.0 x LH; WF 0.55 x WH; WF 0.89 x HE; OOL 1.16 x WOT; posterior ocelli distant from the vertex crest $2.5 \mathrm{x}$ DAO. Vertex convex, with corners slightly rounded. VOL $0.28 \times \mathrm{HE}$.

Mesosoma (Fig. 17). Weakly coriaceous. Pronotal disc with anterior corners acute, anterior carina well-defined, two small ovoid foveae at median posterior region. Notauli complete, slightly widened and convergent posteriorly. Parapsidal furrows absent anteriorly. Scutellar pits large, wider than long, ovoid, inclined and separate by a wide septum. Propodeal disc 1.1 times wider than long, with median, paramedian and sublateral carinae strong and thick, the median complete, the paramedian slightly convergent posteriorly, disc with weak striae, slightly stronger between the paramedian ones; posterior corners foveolate; declivity with median carina complete. Mesopleuron with lower fovea opened in the upper margin, with a rounded and deep central pit (Fig. 27). Fore femora 1.9 times longer than thick. Mid tibiae strongly spinose.

Material examined. Holotype female, BRAZIL, Amazonas: Manaus, Reserva Ducke, 08-15.IV.1992, stick trap (20m), Vidal \& Jailson col. (INPA). Paratypes. BRAZIL. Pará: 1 female, Ourém, Patavateva, 23.VIII.1991, Malaise trap, Mascarenhas, B. col. (MPEG). Maranhão: 1 female, Imperatriz, Bananal, 19-21.VII. 1989, Malaise trap (1.6m), Ramos, F. F. (MPEG).

Variations. Head and thorax without metallic reflection; foveae on the median posterior region of the pronotal disc very weak or absent; parapsidal furrows strong.

Remarks. Species with eyes very large and head little developed behind the eyes. This species runs to $B$. polita Evans, 1964 and B. grossensis Azevedo, 1994, in the key given by AzEvEDo (1994), but differs from those by having the head and thorax with golden reflections.

Etymology. The name refers to the golden reflection of the body.

\section{Bakeriella sulcaticeps sp. nov.}

(Figs. 8, 19, 28)

Description. Female. Length $5.2 \mathrm{~mm}$; LFW $3.6 \mathrm{~mm}$; head, thorax and base of mandibles black with metallic green reflection; propodeum black; metasoma, antennae, mandibles, dark castaneous; palpi castaneous and wings hyaline.

Head (Fig. 8). Clypeus with median lobe truncate, slightly wider than the lateral lobe. First four antennal segments in a ratio of 26:13:8:14; segment XI thicker than long, flagellar pubescence short and subappressed, with some long, erect and suberect setae. Frons coriaceous, brilliant, punctures small and with a linear depression from clypeus to nearly anterior 


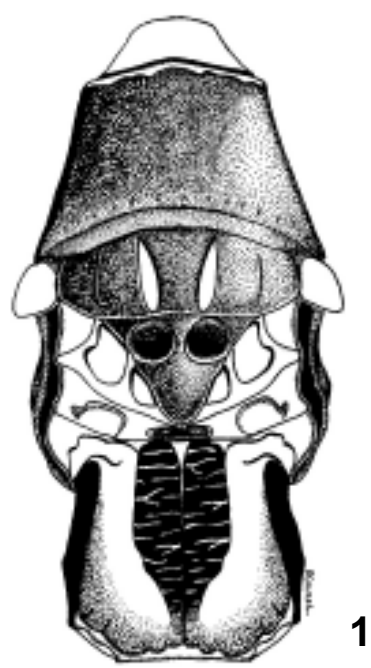

15
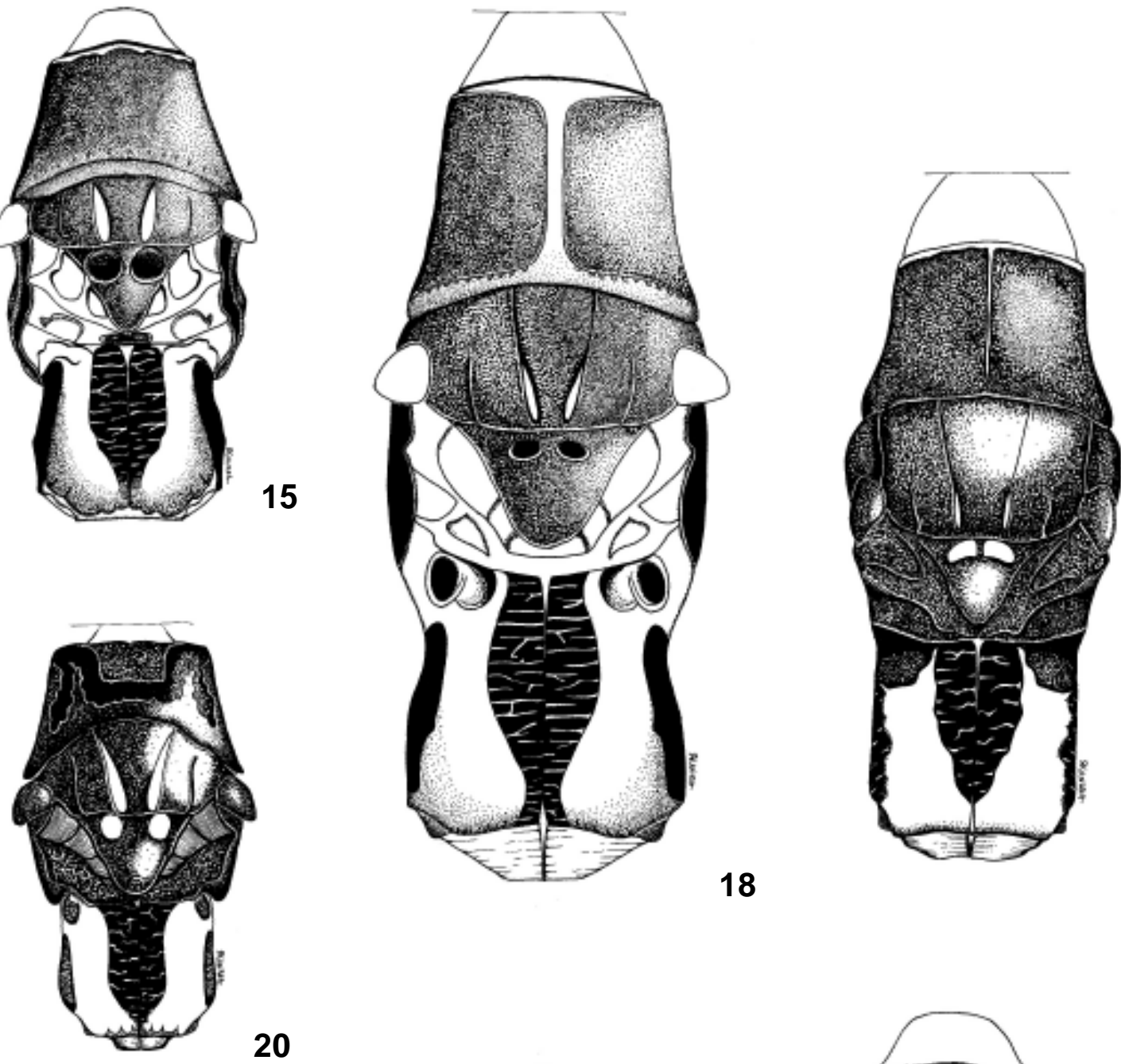

20

18
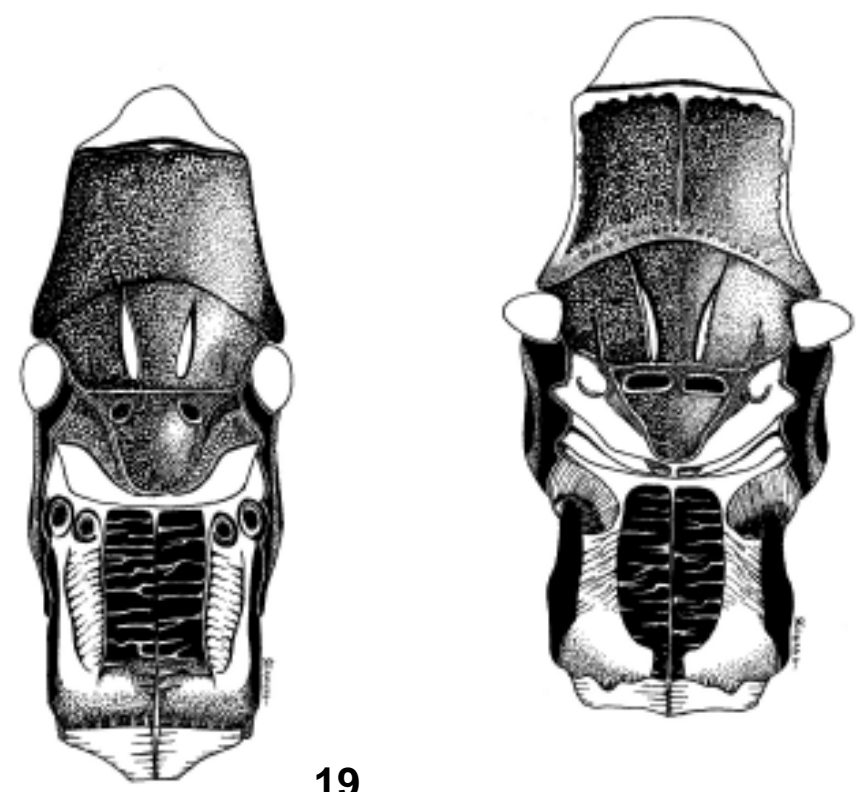

19

21

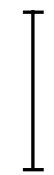

Figs. 15-21. Body, dorsal view. 15, Bakeriella polita Evans, 1964; 16, B. mira Evans, 1997; 17, B. aurata sp. nov.; 18, B. lata sp. nov.; 19, B. sulcaticeps sp. nov.; 20, B. subcarinata Evans, 1965; 21, B. incompleta Azevedo, 1994; scale $=250 \mu \mathrm{m}$. 


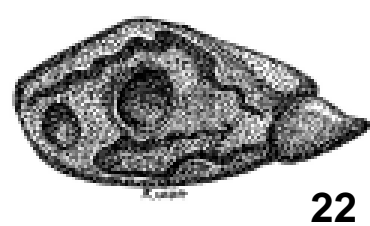

22

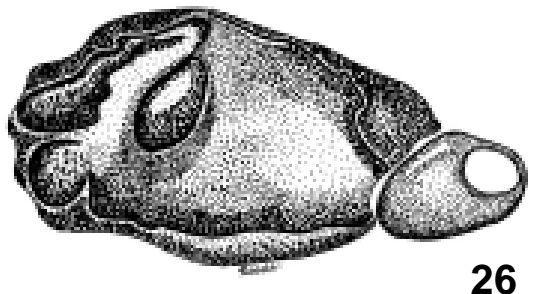
26

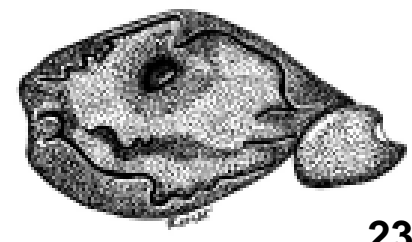

23

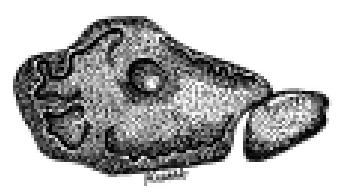

24

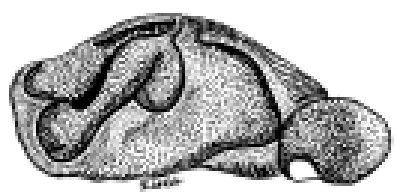

25

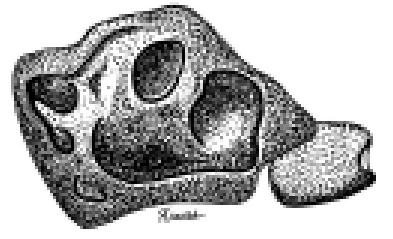

27

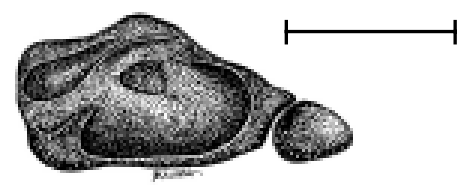

28

Figs. 22-28. Mesopleuron, lateral view. 22, Bakeriella polita Evans, 1964; 23, B. subcarinata Evans, 1965; 24, B. mira Evans, 1997; 25, B. incompleta Azevedo, 1994; 26, B. lata sp. nov.; 27, B. aurata sp. nov.; 28, B. sulcaticeps sp. nov.; scale $=250 \mu \mathrm{m}$.

ocellus. Antennal scrobe not carinate. Eyes glabrous. WH 0.81 x LH; WF 0.59 x WH; WF 0.94 x HE; OOL 1.22 x WOT; posterior ocelli distant from the vertex crest 1.8 x DAO. Vertex nearly straight. Temples parallel. VOL 0.73 x HE.

Mesosoma (Fig. 19). Coriaceous, with punctures small and brilliant. Pronotal disc with anterior corners acute, anterior carina complete and lateral margin of the disc sharpened. Notauli complete, widened and slightly convergent posteriorly. Parapsidal furrows parallel and well-impressed, incomplete anteriorly. Scutellar pits longer than wide, elliptical and inclined, separated by 1.0 time the length of the pit. Propodeal disc 1.04 times longer than wide, with three thick discal carinae, the median complete and the paramedian incomplete and slightly arched, with transverse striae between paramedian carinae and weak striae at anterior corner of the disc, posterior corner foveolate; declivity with median carina complete. Mesopleuron with a complete and large fovea which occupies all surface of mesopleuron and with elliptical central pit (Fig. 28). Fore femora 2.5 times longer than thick. Mid tibiae spinose.

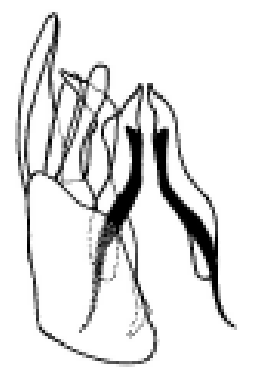

29

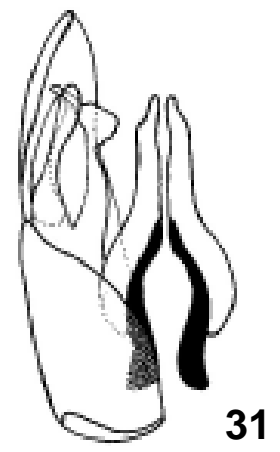

30
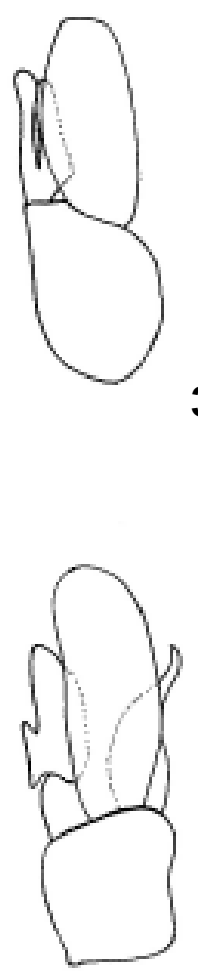

32
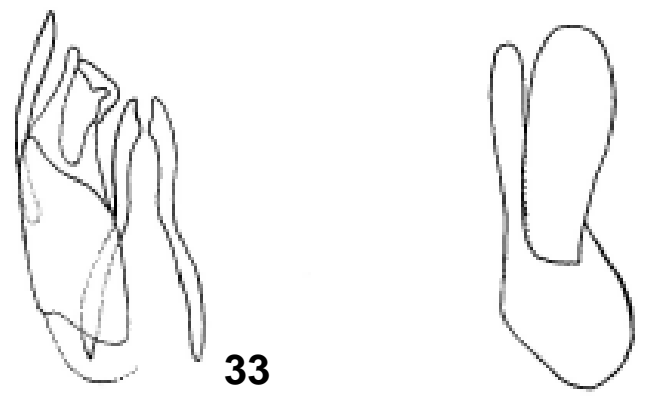

34
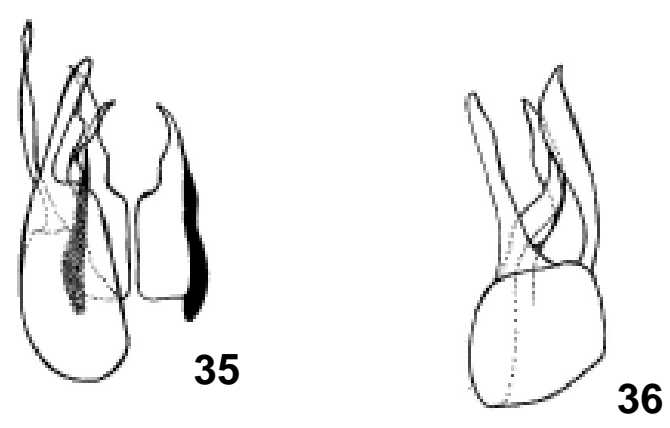

Figs. 29-36. Genitalia: 29, 31, 33, 35 ventral view, 30, 32, 34, 36 lateral view. 29-30, Bakeriella polita Evans, 1964; 31-32, B. incompleta Azevedo, 1994; 33-34, B. mira Evans, 1997; 35-36, B. cristata Evans, 1964; scale = 250 $\mu \mathrm{m}$. 


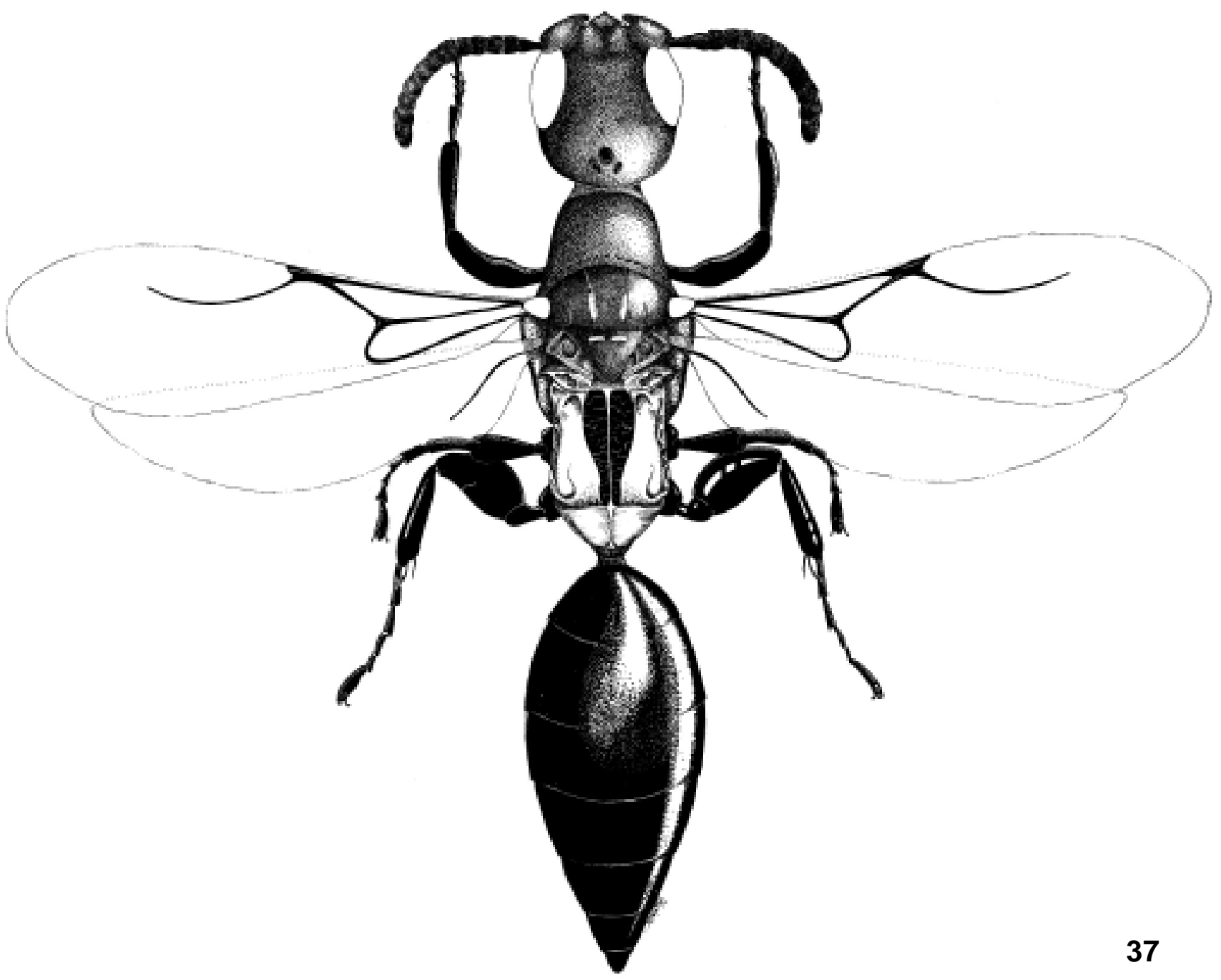

Fig. 37. Bakeriella montivaga Kiffer, 1910.

Material examined. Holotype female, BRAZIL, Amazonas: Manaus, Reserva Ducke 1112, 24.IX.1986, Malaise trap, Klein col. (INPA).

Remarks. This species runs to B. inconspicua Evans, 1964, in the key by AzEveDo (1994), but differs by having scutellar pit more ovoid and green reflections in the head and thorax.

Etymology. The name refers to the linear depression of frons.

Bakeriella cristata Evans, 1964

(Figs. 35, 36)

Bakeriella cristata Evans, 1964: 126, 119 (key); 1973: 200; 1979: 266, 259 (key); De Santis 1980: 332 (cat.); Gordh \& Moczar, 1990: 70 (cat.); Azevedo, 1991: 536; 1994: 149 (key).

This species was known from Bolivia and Brazil (Mato Grosso, São Paulo, Santa Catarina). The specimens from Minas Gerais present median carina very weak or even absent and median pits of the posterior margin of the pronotal disc, larger.
Material examined. BRAZIL. Minas Gerais: 2 males, Belo Horizonte, campus UFMG, Estação Ecológica, 2.XI-5.XII.1996, J.C.R. Fontanelle col. (UFMG). Paraná: 1 male, Foz do Iguaçu, 10.XII. 1966 (DZUP).

Bakeriella flavicornis Kieffer, 1910

Bakeriella flavicornis Kieffer, 1910 (1909): 289; 1914: 444; Evans, 1964: 121 (redescription of type), 119 (key); Evans, 1979: 265, 260 (key); De Santis 1980: 332 (cat.); Gordh \& Moczar, 1990: 70 (cat.).

This species was known only from Brazil (Pará).

Material examined. COSTA RICA. Cartagena, Turrialba, CATIE, 26-29.I.1986, W. Hanson \& G. Bohart col. (EMUS).

Bakeriella floridana Evans, 1964

Bakeriella floridana Evans, 1964: 134, 119 (key); 1970: 347; 1978: 160; 1979: 264, 258 (key); Krombein, 1979: 1211 (cat.); Gordh \& Moczar, 1990: 71 (cat.); Azevedo 1994: 149 (key). 
This species was known from Florida (USA) and Jamaica. Genitalia with paramere wide, apex rounded, cuspis divided in two cylindrical rami with rounded apex, aedeagus bottleshaped, with pre-apical constriction and rounded apex.

Material examined. DOMINICAN REPUBLIC. 1 male, Rancho Arriba, 26.III.1978, L. Masner col. (CNCI); 1 female, Barabona Paraiso Vly., 28.III.1978, Masner, L. col. (CNCI). JAMAICA. 13 males, 1 female, St. Ann, Fern Gully S of Ocho Rios, 7.VII.1982, NF \& JB Johnson col. (OSUC); 8 males, Portland, Rio Grande, 4.VII.1982, NF \& JB Johnson col. (OSUC); 1 male, Hardwar Gap, 3.VII.1966, Howden \& Becker col. (CNCI).

\section{Bakeriella montivaga Kieffer, 1910}

(Fig. 37)

Epyris montivagus Kieffer, 1910: 31.

Epyris bogotensis Kieffer, 1910: 31.

Epyris lindigi Kieffer, 1910: 31; 1914: 309; Evans, 1964: 108; Evans, 1969: 322.

Bakeriella montivaga; Evans, 1979: 261; Gordh \& Moczar, 1990: 71

(cat.); Azevedo, 1994: 148.

This is the most widespread species in the Neotropical region.

Material Examined. HONDURAS. 2 females, Midlessex, 125m.18.III12.IV.1965, E.C. Welling. EQUADOR. 1 male, altitude $2000 \mathrm{~m}, 3 \mathrm{Km}$ N. E. Bacza, 11.II.1982, Borkent, A. col.(CNCI). VENEZUELA. Rancho Grande: 1 female, Edo. Aragua, 18-28.II.1971, Wood col.(CNCI). BRAZIL. Amazonas: 1 male, Manaus, Reserva 1112, 30.X.1985, Klein, B. col., Malaise (INPA). Rondônia: 2 females, Ji - Paraná Gleba, 2528.II.1983, Equipe Aris, J col.(OSUC), 1 undefined sex, Ouro Preto do Oeste, 11- 13.XI.1984, Malaise trap, 1.6m (MPEG).

\section{Bakeriella olmeca Evans, 1964}

Bakeriella olmeca Evans, 1964: 123, 119 (key); 1979: 265, 258 (key); Gordh \& Moczar, 1990: 71 (cat.); Azevedo, 1994: 149 (key).

This species was known from Mexico (Vera Cruz), Belize, Nicaragua, Costa Rica.

Material examined. MEXICO. Vera Cruz: 1 female, Fortin de Las Flores, 29.VI.1964, Raske, A. G. col. (CNCI). BRAZIL. Pará: 1 female, Altamira, 08-22.IV.1986, interception trap, N. Dellagier col. (MPEG).
Acknowledgments. To the Laboratory of Genetics (UFES) for the loan of the microscope used to illustrate the genitalia; to the curators cited in the text for the loan of the material examined and the duplicate retained.

\section{REFERENCES}

Azevedo, C. O. 1991. Espécie nova e notas sobre Bakeriella Kieffer (Hymenoptera, Bethylidae) da região de São Carlos, SP. Revista Brasileira de Entomologia 35(3): 535-538.

Azevedo, C. O. 1994. Descriptions of two new species and notes on the genus Bakeriella Kieffer from Brazil and Ecuador (Hymenoptera, Bethylidae). Journal of Hymenoptera Research 3: 145-150.

De SAntis, L. 1980. Catálogo de los himenópteros brasileños de la serie Parasítica incluyendo Bethyloidea. Curitiba, Universidade Federal do Paraná, 359 p.

Evans, H. E. 1964. A Synopsis of the American Bethylidae (Hymenoptera, Aculeata). Bulletin of the Museum of Comparative Zoology 132(1): 1-222.

Evans, H. E. 1965. Further studies on Neotropical Epyrini (Hymenoptera, Bethylidae). Psyche 72(4): 265-278

Evans, H. E. 1969. A Revision of the genus Epyris in the Americas (Hymenoptera: Bethylidae). Transactions of the American Entomological Society 95(2): 181-352.

Evans, H. E. 1970. West Indian wasps of the subfamilies Epyrinae and Bethylinae (Hymenoptera: Bethylidae). Proceedings of the Entomological Society of Washington 72(3): 340-356.

Evans, H. E. 1973. Further studies on South American Bethylidae (Hymenoptera). Proceedings of the Entomological Society of Washington 75(2): 194-204.

Evans, H. E. 1978. The Bethylidae of America North of Mexico. Memoirs of the American Entomological Institute 27: 1-332.

Evans, H. E. 1979. A reconsideration of the genus Bakeriella (Hymenoptera, Bethylidae). Journal of the New York Entomological Society 87(3): 256-266.

Evans, H. E. 1997. Report on a collection of Bethylidae (Hymenoptera) from Central Florida. Proceedings of the Entomological Society of Washington 99(1): 174-179.

Gordh, G. \& L. Moczar. 1990. A Catalog of the World Bethylidae (Hymenoptera: Aculeata). Memoirs of the American Entomological Institute 46: 1-364.

Harris, R. A. 1979. A glossary of surface sculpturing. Occasional Papers in Entomology 28: 1-31.

Krombein, K. V. 1979. Superfamily Bethyloidea, p. 1203-1251. In: K. V. Krombein; P. D. Hurt JR. \& D. R. Smith (Edit.). Catalog of Hymenoptera in American North of Mexico. Volume 2. Washington, Smithsonian Institution Press.

Kieffer, J. J. 1910. Description de nouveaux Bethylides (Hymen.) Annales de la Societé Entomologique de France 79: 31-56.

KIEffer, J. J. 1914. Bethylinae. Das Tierreich 41: 228-595. 